\title{
Relationship of serum bilirubin concentration to kidney function and 24-hour urine protein in Korean adults
}

\author{
Ho Sik Shin, Yeon Soon Jung and Hark Rim ${ }^{*}$
}

\begin{abstract}
Background: The relationships among serum bilirubin concentration, kidney function and proteinuria have yet to be fully elucidated, nor have these relationships been investigated in Korean adults.

Method: We retrospectively reviewed the medical records of Korean adults who were evaluated at Kosin University Gospel Hospital (Busan, Republic of Korea) during a five-year period from January 2005 to December 2009. We evaluated the relationships among serum bilirubin concentration, estimated glomerular filtration rate (eGFR) and 24-hour urinary protein excretion in a sample of 1363 Korean adults aged 18 years or older.

Results: The values of eGFR $<60 \mathrm{~mL} / \mathrm{min} / 1.73 \mathrm{~m}^{2}$ and 24-hour urine albumin $\geq 150 \mathrm{mg} /$ day were observed in $26.1 \%$ ( $\mathrm{n}$ $=356)$ and $40.5 \%$ ( $n=553$ ) of subjects, respectively. Fasting glucose levels $\geq 126 \mathrm{mg} / \mathrm{dL}$ were observed in $44.9 \%(n=$ 612) of the total sample. After adjustment for potential confounding factors including demographic characteristics, comorbidities and other laboratory measures, total serum bilirubin was positively associated with eGFR and negatively associated with proteinuria both in the whole cohort and in a subgroup of diabetic individuals.

Conclusions: To our knowledge, this is the first hospital-based study specifically aimed at examining the relationships among serum total bilirubin concentration, 24-hour urine protein and kidney function in Korean adults. We demonstrated that serum total bilirubin concentration was negatively correlated with 24-hour urine protein and positively correlated with eGFR in Korean non-diabetic and diabetic adults.
\end{abstract}

Keywords: Proteinuria, Bilirubin, Glomerular filtration rate

\section{Background}

The prevalence of chronic kidney disease is increasing worldwide [1,2]. Reduced eGFR and abnormal proteinuria have been associated with increased risk of end stage renal disease (ESRD), cardiovascular disease and other comorbidities [3-6]. Because renal disease often progresses to ESRD, the identification of risk factors for kidney disease progression is essential.

Increased concentrations of serum bilirubin have long been used as a marker of liver dysfunction. In addition, serum bilirubin is not merely an end product of heme degradation but is also a potent antioxidant that acts via inhibitions of NADPH oxidase, a key source of oxidants

\footnotetext{
* Correspondence: rimhark@hanmail.net

* Correspondence: rimhark@hanmail.net Busan, Republic of Korea
}

(c) 2011 Shin et al; licensee BioMed Central Ltd. This is an Open Access article distributed under the terms of the Creative Commons Attribution License (http://creativecommons.org/licenses/by/2.0), which permits unrestricted use, distribution, and reproduction in any medium, provided the original work is properly cited. kinase $\mathrm{C}$ activity [7-9].

Information on the associations of serum bilirubin concentration with renal function and proteinuria is limited and controversial. Fukui et al. found that total serum bilirubin was positively associated with eGFR and negatively associated with albuminuria in a hospitalbased sample of 633 Japanese type 2 diabetic patients [10], indicating that bilirubin has a potential renoprotective effect. In contrast, Targher et al. found that a higher total serum bilirubin was significantly associated with lower eGFR in both non-diabetic and diabetic individuals in a group of 2678 unselected outpatients 35 years of age or older [11].

To date, the associations of serum bilirubin concentration with kidney function and proteinuria have not been established in a Korean adult population. Therefore, we 
examined the associations among serum bilirubin concentration, eGFR and the degree of 24-hour urinary protein excretion in patients at Kosin University Gospel Hospital (Busan, Republic of Korea) during a five-year period from January 2005 to December 2009.

\section{Methods \\ Patients}

We retrospectively reviewed the medical records of Korean adults patients who had visited Kosin University Gospel Hospital (Busan, Republic of Korea) from January 2005 to December 2009 and evaluated the relationships among serum bilirubin concentration, eGFR and 24-hour urinary protein excretion in a sample of 1363 Korean adults aged 18 years or older (669 men, 694 women, aged $54.6 \pm 15.1$ years, range $18-93$ years). The study was reviewed and approved by the Ethics Committee of Kosin University Gospel Hospital.

\section{Clinical and biochemical assessments}

Type 2 diabetes was diagnosed according to the Report of the Expert Committee on the Diagnosis and Classification of Diabetes Mellitus [12]. Nephropathy was graded as follows: normoproteinuria, urinary protein excretion less than $150 \mathrm{mg} /$ day and macroproteinuria, greater than $150 \mathrm{mg} /$ day.

As a surrogate for measuring renal function in the subjects, we estimated the GFR using a simplified form of the Modification of Renal Disease (MDRD) equation [13]. The equation is as follows:

$$
\mathrm{GFR}=186 \times[\mathrm{Scr}]^{-1.154} \times[\text { Age }]^{-0.203} \times[0.742 \text { if patient is female }]
$$

The exclusion criteria were as follows:

1) patients with malignant disease, liver cirrhosis, or hematologic disease;

2) patients with advanced renal dysfunction (serum creatinine level higher than $2.0 \mathrm{mg} / \mathrm{dL}$ );

3) patients whose serum bilirubin concentrations were greater than $1.2 \mathrm{mg} / \mathrm{dL}$ due to the high possibility of Gilbert syndrome.

4) patients with chronic hepatitis B or C

Total serum bilirubin concentrations (normal ranges: $0.2-1.0 \mathrm{mg} / \mathrm{dL}$ ) were measured using an enzymatic method with bilirubin oxidase on an automatic analyzer (Hitachi 7600). Serum total cholesterol, high-density lipoprotein cholesterol, and triglyceride concentrations were assessed using standard enzymatic methods. Twentyfour-hour urine samples were collected from patients who demonstrated proteinuria in a dipstick urine test.

\section{Statistical analysis}

The results are presented as the mean \pm SD. We used Student's $t$ test to compare the means and Pearson's correlation coefficient to evaluate the relationships between parameters. The association between serum total bilirubin and eGFR and the association between serum total bilirubin and 24 hour urine protein were investigated using linear (adjusted) regression models in the whole group and in subgroups of patients stratified by diabetes status. The covariates included in adjusted regression models were age, sex, diabetes, hypertension, total cholesterol, LDL-cholesterol, HDL-cholesterol and triglyceride. The results were considered significant when the $P$ value was less than 0.05 . All statistical analyses were performed using the Statistical Package for the Social Sciences (SPSS) version 12.0 (SPSS Inc., Chicago, IL, USA).

\section{Results}

Characteristics of the 1363 subjects enrolled in this study are shown in Table 1.

\section{Table 1 Clinical characteristics of subjects}

\begin{tabular}{|c|c|}
\hline Variable & Mean \pm s.d. \\
\hline $\bar{n}$ & 1,363 \\
\hline Age (years) & $55.6 \pm 14.1$ \\
\hline \multicolumn{2}{|l|}{ Sex, $\%$} \\
\hline Males & 49.1 \\
\hline Females & 50.9 \\
\hline Diabetes, $\%$ & 44.9 \\
\hline Hypertension, $\%$ & 14.0 \\
\hline \multicolumn{2}{|l|}{ Measurements } \\
\hline Urine protein, mg/day & $806 \pm 2,150$ \\
\hline $\mathrm{WBC}, \mathrm{mm}^{3}$ & $7,619 \pm 3,083$ \\
\hline $\mathrm{Hb}, \mathrm{g} / \mathrm{dL}$ & $12.2 \pm 1.9$ \\
\hline Platelet, $\mathrm{mm}^{3}$ & $260,398 \pm 98,162$ \\
\hline Protein, g/dL & $6.7 \pm 2.7$ \\
\hline Albumin, $\mathrm{g} / \mathrm{dL}$ & $3.8 \pm 0.6$ \\
\hline Total cholesterol, mg/dL & $204 \pm 77$ \\
\hline LDL Cholesterol, mg/dL & $115 \pm 43$ \\
\hline HDL cholesterol, mg/dL & $44 \pm 15$ \\
\hline Triglycerides, mg/dL & $158 \pm 209$ \\
\hline AST, IU/L & $28 \pm 22$ \\
\hline$A L T, I U / L$ & $27 \pm 24$ \\
\hline Fasting blood glucose, $\mathrm{mg} / \mathrm{dL}$ & $144 \pm 73$ \\
\hline $\mathrm{BUN}, \mathrm{mg} / \mathrm{dL}$ & $18.6 \pm 10.4$ \\
\hline Creatinine, $\mathrm{mg} / \mathrm{dL}$ & $1.16 \pm 0.64$ \\
\hline eGFR, $\mathrm{mL} / \mathrm{min} / 1.73 \mathrm{~m}^{2}$ & $75 \pm 31$ \\
\hline Uric acid, IU/L & $5.4 \pm 2.0$ \\
\hline Sodium, mEq/L & $140.6 \pm 4.8$ \\
\hline Potassium, mEq/L & $4.2 \pm 0.6$ \\
\hline Calcium, mg/dL & $9.1 \pm 0.7$ \\
\hline Phosphorus, mg/dL & $4.0 \pm 3.1$ \\
\hline Chloride, $\mathrm{mEq} / \mathrm{L}$ & $102 \pm 11$ \\
\hline total $\mathrm{CO}_{2}, \mathrm{mEq} / \mathrm{L}$ & $26.4 \pm 4.9$ \\
\hline Total Bilirubin, mg/dL & $0.75 \pm 0.21$ \\
\hline Direct Bilirubin, mg/dL & $0.30 \pm 0.09$ \\
\hline
\end{tabular}


Among the 1363 adult subjects, the mean age and total bilirubin were $55.6( \pm 14.1)$ years and $0.75( \pm 0.21)$ $\mathrm{mg} / \mathrm{dL}$, respectively. An eGFR $<60 \mathrm{~mL} / \mathrm{min} / 1.73 \mathrm{~m}^{2}$ and a 24-hour urine protein $\geq 150 \mathrm{mg} /$ day were present in $26.1 \%(\mathrm{n}=356)$ and $40.5 \%(\mathrm{n}=553)$ of the subjects, respectively. Diabetes and hypertension were present in $44.9 \%(n=612)$ and $14.0 \%(n=191)$ of patients.

The clinical and biochemical characteristics of subjects stratified according to eGFR category are summarized in Table 2. Compared with patients with normal or nearnormal eGFR, persons with lower eGFR were older, more likely to be male, and had greater prevalence for high serum total bilirubin concentration. A positive correlation was found between serum total bilirubin concentration and eGFR in all subjects and in diabetic patients $(\mathrm{r}=0.128, \mathrm{p}=0.0001 ; \mathrm{r}=0.202, \mathrm{p}=0.0001)$ (Figure 1,2). An inverse correlation was found between total serum bilirubin concentration and 24-hour urine albumin in all subjects and in subjects with diabetes $(\mathrm{r}=$ $-0.228, \mathrm{p}=0.0001 ; \mathrm{r}=-0.227, \mathrm{p}=0.0001$ ) (Figure 3, 4).

When participants were stratified into categories based on proteinuria (Table 3), persons with higher proteinuria were hypoalbuminemic, more likely to be male, hypercholesterolemic (although level of LDL was

Table 2 Age-gender standardized baseline demographics and laboratory results accordings to eGFR in the entire cohort $(n=1,363)$

\begin{tabular}{|c|c|c|c|c|c|}
\hline eGFR Characteristics & $\begin{array}{l}\geq 90 \mathrm{~mL} / \mathrm{min} / \\
1.73 \mathrm{~m}^{2}, \mathrm{n}=564\end{array}$ & $\begin{array}{l}60-89 \mathrm{~mL} / \mathrm{min} / 1.73 \mathrm{~m}^{2} \\
\mathrm{n}=443\end{array}$ & $\begin{array}{l}30-59 \mathrm{~mL} / \mathrm{min} / 1.73 \mathrm{~m}^{2} \\
\mathrm{n}=265\end{array}$ & $\begin{array}{l}15-29 \mathrm{~mL} / \mathrm{min} / 1.73 \mathrm{~m}^{2} \\
\mathrm{n}=91\end{array}$ & $\begin{array}{l}\mathrm{p}- \\
\text { value }\end{array}$ \\
\hline Age, years & $50.1 \pm 13.8$ & $57.3 \pm 13.8$ & $59.3 \pm 13.7$ & $59.4 \pm 14.6$ & 0.0001 \\
\hline$T^{1)}$ & a & b, c & c & c & \\
\hline \multicolumn{6}{|l|}{ Sex, $\%$} \\
\hline Males & 46 & 48.3 & 54.3 & 56 & \\
\hline Females & 54 & 51.7 & 45.7 & 44 & \\
\hline Diabetes,\% & 52.8 & 45.1 & 32.8 & 29.4 & \\
\hline Hypertension, $\%$ & 10.1 & 12.1 & 23.3 & 21.2 & \\
\hline \multicolumn{6}{|l|}{ Measurements } \\
\hline Urine protein, mg/day & $572 \pm 1,871$ & $744 \pm 2,366$ & $1,231 \pm 2,236$ & $2,050 \pm 3047$ & 0.0001 \\
\hline$T^{1)}$ & a & $a, b$ & $b$ & c & \\
\hline $\mathrm{WBC}, \mathrm{mm}^{3}$ & $7,420 \pm 3,116$ & $7,534 \pm 3,112$ & $7,940 \pm 3,003$ & $7,909 \pm 2,967$ & 0.252 \\
\hline $\mathrm{Hb}, \mathrm{g} / \mathrm{dL}$ & $12.5 \pm 1.7$ & $12.5 \pm 1.7$ & $11.6 \pm 1.9$ & $10.8 \pm 1.8$ & 0.0001 \\
\hline$T^{1)}$ & a & a & $b$ & c & \\
\hline Platelet, $\mathrm{mm}^{3}$ & $276,222 \pm 103,955$ & $259,255 \pm 92,563$ & $250,831 \pm 96,831$ & $235,755 \pm 87,964$ & 0.002 \\
\hline$T^{1)}$ & a & $a, b$ & $a, b$ & $b$ & \\
\hline Protein, g/dL & $6.7 \pm 3.3$ & $6.6 \pm 0.9$ & $6.7 \pm 3.8$ & $6.3 \pm 0.8$ & 0.447 \\
\hline Albumin, g/dL & $3.8 \pm 0.7$ & $3.8 \pm 0.6$ & $3.6 \pm 0.7$ & $3.5 \pm 0.6$ & 0.0001 \\
\hline$T^{1)}$ & a & a & $a, b$ & $\mathrm{~b}$ & \\
\hline $\begin{array}{l}\text { Total cholesterol, mg/ } \\
\mathrm{dL}\end{array}$ & $204 \pm 93$ & $208 \pm 71$ & $207 \pm 87$ & $205 \pm 72$ & 0.215 \\
\hline LDL Cholesterol, mg/dL & $126 \pm 55$ & $113 \pm 44$ & $109 \pm 34$ & $112 \pm 40$ & 0.103 \\
\hline HDL cholesterol, mg/dL & $46 \pm 16$ & $45 \pm 16$ & $42 \pm 14$ & $40 \pm 12$ & 0.001 \\
\hline$T^{1)}$ & a & $a, b$ & $b, c$ & c & \\
\hline Triglycerides, mg/dL & $170 \pm 360$ & $151 \pm 127$ & $155 \pm 95$ & $180 \pm 192$ & 0.657 \\
\hline AST, IU/L & $29 \pm 27$ & $29 \pm 20$ & $27 \pm 16$ & $29 \pm 38$ & 0.108 \\
\hline$A L T, I U / L$ & $28 \pm 25$ & $28 \pm 23$ & $24 \pm 20$ & $26 \pm 47$ & 0.197 \\
\hline $\begin{array}{l}\text { Fasting blood glucose, } \\
\mathrm{mg} / \mathrm{dL}\end{array}$ & $153 \pm 81$ & $142 \pm 74$ & $127 \pm 62$ & $127 \pm 69$ & 0.0001 \\
\hline$T^{1)}$ & a & $a, b$ & $b$ & $b$ & \\
\hline $\mathrm{BUN}, \mathrm{mg} / \mathrm{dL}$ & $12.5 \pm 4.5$ & $16.1 \pm 5.6$ & $24.3 \pm 9.4$ & $38.1 \pm 15.5$ & 0.0001 \\
\hline$T^{1)}$ & a & a & $b$ & c & \\
\hline Creatinine, $\mathrm{mg} / \mathrm{dL}$ & $0.71 \pm 0.13$ & $0.96 \pm 0.16$ & $1.51 \pm 0.33$ & $2.86 \pm 0.69$ & 0.0001 \\
\hline$T^{1)}$ & a & $b$ & c & $d$ & \\
\hline Total Bilirubin, mg/dL & $0.77 \pm 0.22$ & $0.76 \pm 0.21$ & $0.72 \pm 0.22$ & $0.67 \pm 0.21$ & 0.0001 \\
\hline$T^{1)}$ & $a, b$ & $a, b$ & $b, c$ & c & \\
\hline Direct Bilirubin, mg/dL & $0.31 \pm 0.09$ & $0.30 \pm 0.09$ & $0.30 \pm 0.10$ & $0.28 \pm 0.09$ & 0.222 \\
\hline
\end{tabular}

1) The same letters indicate non-significant difference between groups based on Turey's multiple comparison test 


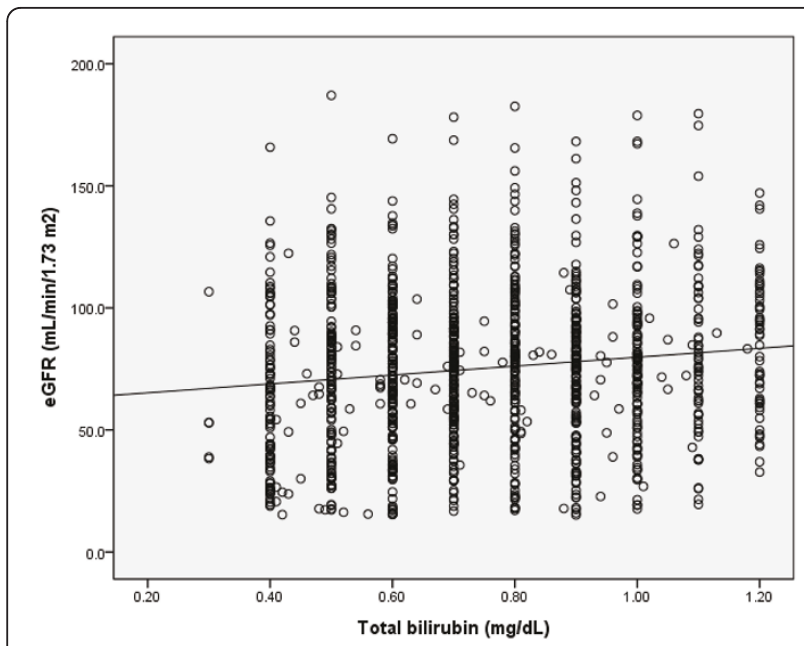

Figure 1 Correlation between serum total bilirubin concentration and eGFR in whole subjects $(r=0.128, p=$ 0.0001).

similar) and had lower values of total bilirubin compared with those of patients with normal proteinuria.

When participants were stratified into categories based on fasting blood glucose (Table 4), diabetic patients were hypoalbuminuric compared with non-diabetic patients. No significant differences were found with regard to serum total bilirubin concentration between participants with normal and abnormal fasting blood glucose levels.

\section{Discussion}

To our knowledge, this is the first hospital-based study specifically aimed at examining the associations among

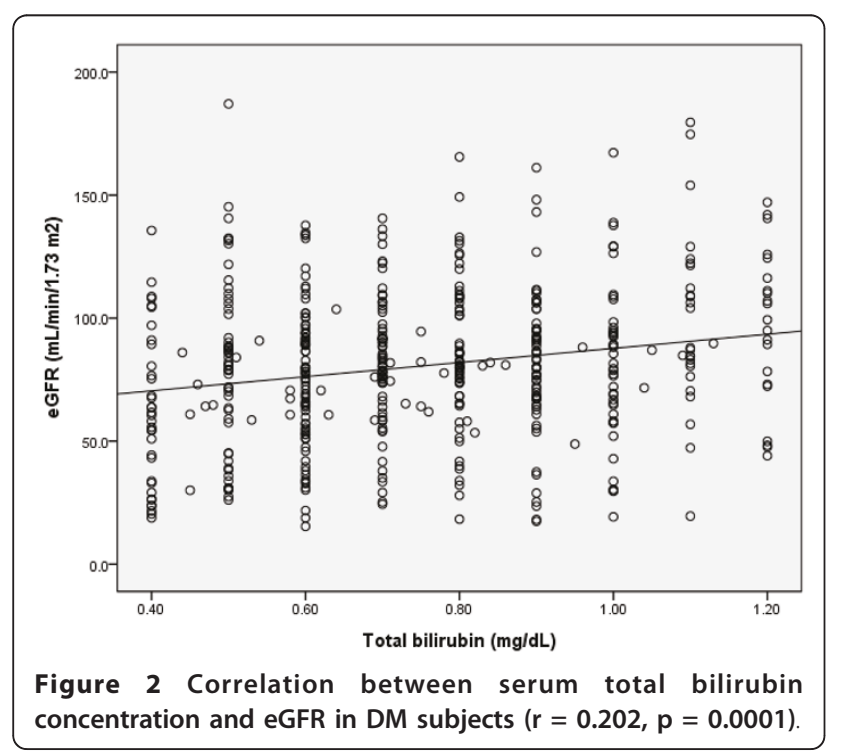

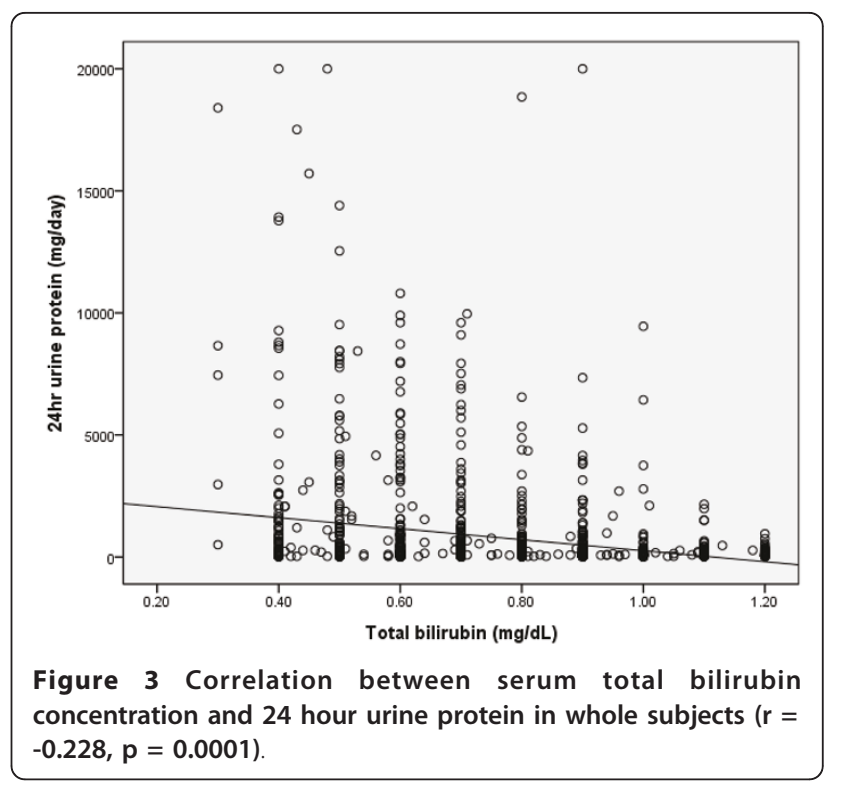

serum total bilirubin concentration, 24-hour urine protein and kidney function in Korean adults.

We retrospectively reviewed the medical records of 1363 adults aged 18 years or older who were seen at Kosin University Gospel Hospital (Busan, Republic of Korea) in the five-year period from January 2005 to December 2009. This study demonstrated that serum total bilirubin concentration was negatively correlated with 24-hour urine protein and was positively correlated with eGFR in Korean non-diabetic and diabetic adults.

Our findings are in contrast to the results of Targher et al. [11] in their observational large hospital-based sample of 2678 adult outpatients (mean age: $55 \pm 18$

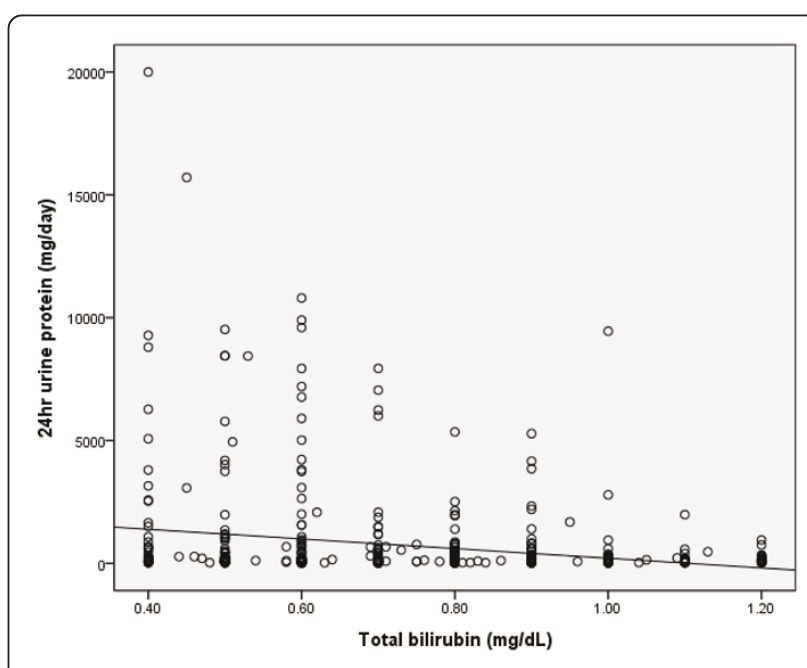

Figure 4 Correlation between serum total bilirubin concentration and 24 hour urine protein in DM subjects ( $r=$ $-0.227, p=0.0001$ ). 
Table 3 Age-gender standardized baseline demographics and laboratory results according to 24 urine protein excretion in the entire cohort $(n=1,363)$

\begin{tabular}{|c|c|c|c|}
\hline $\begin{array}{l}24 \text { hour urine protein } \\
\text { (mg/day) }\end{array}$ & $<150$ & $\geq 150$ & $P$ value \\
\hline Characteristics & $n=810$ & $n=553$ & \\
\hline Age, years & $55.9 \pm 13.9$ & $55.9 \pm 14.9$ & 0.642 \\
\hline Sex, $\%$ & & & 0.0001 \\
\hline Males & 44.7 & 55.5 & \\
\hline Females & 55.3 & 44.5 & \\
\hline Diabetes,\% & 47.4 & 41.2 & 0.027 \\
\hline Hypertension,\% & 8.7 & 21.6 & 0.0001 \\
\hline \multicolumn{3}{|c|}{ eGFR,\%, mL/min $/ 1.73 \mathrm{~m}^{2}$} & 0.0001 \\
\hline$\geq 90$ & 35.8 & 23.1 & \\
\hline $60-89$ & 44.4 & 31.1 & \\
\hline $30-59$ & 16.6 & 31.5 & \\
\hline $15-29$ & 3.2 & 14.3 & \\
\hline \multicolumn{4}{|l|}{ Measurements } \\
\hline WBC, $\mathrm{mm}^{3}$ & $7,296 \pm 2,940$ & $8,044 \pm 3,216$ & 0.0001 \\
\hline $\mathrm{Hb}, \mathrm{g} / \mathrm{dL}$ & $12.5 \pm 1.7$ & $11.8 \pm 1.9$ & 0.0001 \\
\hline Platelet, $\mathrm{mm}^{3}$ & $257,821 \pm 93,576$ & $263,793 \pm 103,896$ & 0.315 \\
\hline Protein, g/dL & $6.8 \pm 1.6$ & $6.5 \pm 3.7$ & 0.097 \\
\hline Albumin, g/dL & $4.0 \pm 0.4$ & $3.5 \pm 0.7$ & 0.0001 \\
\hline $\begin{array}{l}\text { Total cholesterol, } \\
\mathrm{mg} / \mathrm{dL}\end{array}$ & $194 \pm 49$ & $219 \pm 103$ & 0.0001 \\
\hline $\begin{array}{l}\text { LDL Cholesterol, } \\
\mathrm{mg} / \mathrm{dL}\end{array}$ & $115 \pm 37$ & $115 \pm 49$ & 0.952 \\
\hline $\begin{array}{l}\mathrm{HDL} \text { cholesterol, } \\
\mathrm{mg} / \mathrm{dL}\end{array}$ & $45 \pm 15$ & $43 \pm 16$ & 0.023 \\
\hline $\begin{array}{l}\text { Triglycerides, } \\
\mathrm{mg} / \mathrm{dL}\end{array}$ & $148 \pm 151$ & $174 \pm 272$ & 0.037 \\
\hline AST, IU/L & $27 \pm 20$ & $29 \pm 25$ & 0.139 \\
\hline $\mathrm{ALT}, \mathrm{IU} / \mathrm{L}$ & $27 \pm 21$ & $27 \pm 28$ & 0.898 \\
\hline BUN, mg/dL & $16.3 \pm 7.9$ & $21.7 \pm 12.4$ & 0.0001 \\
\hline Creatinine, mg/dL & $0.99 \pm 0.41$ & $1.39 \pm 0.79$ & 0.0001 \\
\hline $\begin{array}{l}\text { Total Bilirubin, } \\
\mathrm{mg} / \mathrm{dL}\end{array}$ & $0.78 \pm 0.20$ & $0.71 \pm 0.22$ & 0.0001 \\
\hline $\begin{array}{l}\text { Direct Bilirubin, } \\
\mathrm{mg} / \mathrm{dL}\end{array}$ & $0.30 \pm 0.09$ & $0.29 \pm 0.09$ & 0.003 \\
\hline
\end{tabular}

years; $43 \%$ male), including 210 diabetic patients. In that study, they found that serum total bilirubin was inversely associated with eGFR in both non-diabetic ( $\mathrm{r}=$ -0.17; $\mathrm{p}<0.0001)$ and diabetic patients $(\mathrm{r}=-0.14 ; \mathrm{p}<$ 0.05). However, no information was available on albuminuria, comorbidites, alcohol consumption or other important potential confounders [11]. In this study, we could not analyzed the effects of alcohol and smoking on proteinuria, because we were unable to locate data on alcohol drinking and smoking.

The significant associations between total serum bilirubin and eGFR or albuminuria observed in diabetic individuals of our cohort were the same as those from Fukui et al. [10]. That previous study found that total serum bilirubin was positively associated with eGFR and
Table 4 Age-gender standardized baseline demographics and laboratory results according to fasting blood glucose $(n=1,363)$

\begin{tabular}{|c|c|c|c|}
\hline $\begin{array}{l}\text { Fasting blood glucose, } \\
\mathrm{mg} / \mathrm{dL}\end{array}$ & $<126$ & $\geq 126$ & $\begin{array}{l}\mathrm{P} \\
\text { value }\end{array}$ \\
\hline \multicolumn{4}{|l|}{ Characteristics } \\
\hline Age, years & $53.9 \pm 14.6$ & $57.7 \pm 13.1$ & 0.0001 \\
\hline Sex, $\%$ & & & 0.414 \\
\hline Males & 48.1 & 50.3 & \\
\hline Females & 51.9 & 49.7 & \\
\hline eGFR,\%, mL/min/1.73 $\mathrm{m}^{2}$ & & & 0.0001 \\
\hline$\geq 90$ & 27.5 & 34.1 & \\
\hline $60-89$ & 36.3 & 41.9 & \\
\hline $30-59$ & 26.6 & 18.2 & \\
\hline $15-29$ & 9.6 & 5.8 & \\
\hline \multicolumn{4}{|l|}{ Measurements } \\
\hline $\begin{array}{l}24 \text { hour urine protein, } \\
\mathrm{mg} / \text { day }\end{array}$ & $913 \pm 2,350$ & $676 \pm 1,870$ & 0.038 \\
\hline WBC, $\mathrm{mm}^{3}$ & $7,368 \pm 2,942$ & $7,965 \pm 3,239$ & 0.001 \\
\hline $\mathrm{Hb}, \mathrm{g} / \mathrm{dL}$ & $12.0 \pm 1.8$ & $12.3 \pm 1.8$ & 0.003 \\
\hline Platelet, $\mathrm{mm}^{3}$ & $\begin{array}{l}258,479 \pm \\
97,902\end{array}$ & $\begin{array}{l}263,037 \pm \\
98,560\end{array}$ & 0.438 \\
\hline Protein, g/dL & $6.7 \pm 3.2$ & $6.6 \pm 1.9$ & 0.639 \\
\hline Albumin, g/dL & $3.7 \pm 0.7$ & $3.8 \pm 0.5$ & 0.046 \\
\hline Total cholesterol, mg/dL & $207 \pm 78$ & $201 \pm 75$ & 0.211 \\
\hline LDL Cholesterol, mg/dL & $114 \pm 47$ & $115 \pm 38$ & 0.877 \\
\hline HDL cholesterol, mg/dL & $46 \pm 16$ & $42 \pm 14$ & 0.0001 \\
\hline Triglycerides, mg/dL & $140 \pm 97$ & $179 \pm 286$ & 0.002 \\
\hline AST, IU/L & $28 \pm 20$ & $28 \pm 25$ & 0.861 \\
\hline$A L T, I U / L$ & $24 \pm 19$ & $30 \pm 29$ & 0.0001 \\
\hline $\mathrm{BUN}, \mathrm{mg} / \mathrm{dL}$ & $19.0 \pm 11.0$ & $18.1 \pm 9.6$ & 0.16 \\
\hline Creatinine, mg/dL & $1.24 \pm 0.69$ & $1.06 \pm 0.55$ & 0.0001 \\
\hline Total Bilirubin, mg/dL & $0.75 \pm 0.21$ & $0.76 \pm 0.21$ & 0.499 \\
\hline Direct Bilirubin, mg/dL & $0.30 \pm 0.09$ & $0.30 \pm 0.08$ & 0.705 \\
\hline eGFR, $\mathrm{mL} / \mathrm{min} / 1.73 \mathrm{~m}^{2}$ & $71 \pm 31$ & $80 \pm 30$ & 0.0001 \\
\hline
\end{tabular}

negatively associated with albuminuria in a hospitalbased sample of 633 Japanese type 2 diabetic patients (mean age: $64.4 \pm 11.5$ years; $52 \%$ male). However, in that study, no adjustment was made for important confounders, such as eGFR. In our study, a positive correlation was found between total serum bilirubin concentration and eGFR in all subjects as well as in diabetic patients.

Based on in vitro as well as animal studies, bilirubin is generally recognized as an important antioxidant substance. Kumar et al. demonstrated that serum bilirubin concentration is inversely correlated with a marker of oxidative stress and is positively correlated with antioxidative enzyme activities such as those of superoxide dismutase, catalase, and glutathione peroxidase [14]. These results are also supported by clinical studies focused on the protective effects of serum bilirubin concentration on atherosclerosis [15-17]. In this study, serum bilirubin 
concentration correlated negatively with proteinuria and positively correlated with renal function, and total cholesterol in the normal proteinuria group level was lower than that in the abnormal proteinuria group. However, we were unable to assess the antioxidant effect of serum bilirubin, because tests for an oxidative stress marker and antioxidant enzyme were not carried out.

In addition to being an antioxidant, bilirubin also has anticomplement properties that protect against inflammation [18]. Furthermore, bilirubin has been suggested to have cytoprotective properties through its influence on protein kinase $C$ [19]. Through these mechanisms, bilirubin could protect diabetic patients from the development and progression of diabetic nephropathy [20-23]. However, in this study, the 24-hour proteinuria level in the diabetic group was lower than that in the non-diabetic group because CKD patients were included in the non-diabetic group.

In results of this study, we might think serum bilirubin concentration may be utilized as a provisional new risk factor of diabetic nephropathy that can be measured easily in the clinical laboratory and applied in medical practice.

It could be hypothesized that the bilirubin-kidney dysfunction relationship primarily reflects the association of serum bilirubin concentration with non-alcoholic fatty liver disease (NAFLD). NAFLD represents the most common cause of mild to moderate increases in serum bilirubin and other liver enzymes in Western countries [24]. Recent studies have found that NAFLD is independently associated with an increased incidence of CKD in both non-diabetic and diabetic populations [25,26].

Limitations of our study include its cross-sectional design, which allows us to identify only associations and should not yield any conclusions about causation. In addition, results of this study may not be applicable to the general population or to patients with type 2 diabetes in a primary care clinic because the data were collected from patients in an outpatient clinic of a university hospital. This study's results are not definitive because a Pearson's correlation coefficient of less than \pm 0.25 is generally considered to be a weak correlation. We think prompt further research into this interesting correlation will be needed. Second, we were unable to explain the reason why both the non-diabetic and diabetic group had the same results. Third, liver ultrasonography for diagnosing NAFLD was not performed. Finally, we used eGFR instead of a directly measured GFR to assess renal function. It is known that current eGFR experiences greater inaccuracy in populations with no known CKD than in those with CKD. Nonetheless, the current eGFR technique facilitates the detection, evaluation, and management of renal disease.
To our knowledge, this is the first study to investigate the relationship between serum bilirubin concentration and 24-hour urine protein excretion in non-diabetic subjects and in patients with type 2 diabetes. Although we are unable to determine whether hypobilirubinemia has a causative effect, these findings suggest that hypobilirubinemia combined with diabetes might be associated with advanced diabetic nephropathy. Large prospective trials are needed to better assess the effects of bilirubin on diabetic nephropathy in patients with type 2 diabetes.

\section{Conclusions}

our findings suggest that increasing serum total bilirubin concentration is associated with increasing eGFR and decreasing albuminuria in Korean non-diabetic and diabetic adults.

\section{Acknowledgements}

In memory of Ms. Eum No-Mi, a founder of Ahnna Social Welfare Institute, Busan, Korea. (2010)

\section{Authors' contributions}

HSS, M.D. and HR, M.D. participated in the design of the study and performed the statistical analysis. YSJ, M.D. conceived of the study, and participated in its design and coordination. All authors read and approved the final manuscript.

\section{Competing interests}

The authors declare that they have no competing interests.

Received: 17 January 2011 Accepted: 28 June 2011

Published: 28 June 2011

\section{References}

1. Coresh J, Selvin E, Stevens LA, Manzi J, Kusek JW, Eggers P, Van Lente F, Levey AS: Prevalence of chronic kidney disease in the united states. JAMA 2007, 298:2038-2047.

2. Hsu CY, McCulloch CE, Fan D, Ordonez JD, Chertow GM, Go AS: Community-based incidence of acute renal failure. Kidney Int 2007, 72:208-212.

3. Muntner P, He J, Hamm L, Loria C, Whelton PK: Renal insufficiency and subsequent death resulting from cardiovascular disease in the united states. J Am Soc Nephrol 2002, 13:745-753.

4. Go AS, Chertow GM, Fan D, McCulloch CE, Hsu CY: Chronic kidney disease and the risks of death, cardiovascular events, and hospitalization. $N$ Engl $J$ Med 2004, 351:1296-1305.

5. Rifkin DE, Shlipak MG, Katz R, Fried LF, Siscovick D, Chonchol M, Newman $A B$, Sarnak MJ: Rapid kidney function decline and mortality risk in older adults. Arch Intern Med 2008, 168:2212-2218.

6. van Domburg RT, Hoeks SE, Welten GM, Chonchol M, Elhendy A, Poldermans D: Renal insufficiency and mortality in patients with known or suspected coronary artery disease. J Am Soc Nephrol 2008, 19:158-163.

7. Stocker R, Glazer AN, Ames BN: Antioxidant activity of albumin-bound bilirubin. Proc Natl Acad Sci USA 1987, 84:5918-5922.

8. Lanone S, Bloc S, Foresti R, Almolki A, Taille C, Callebert J, Conti M, Goven D, Aubier M, Dureuil B, El-Benna J, Motterlini R, Boczkowski J: Bilirubin decreases nos 2 expression via inhibition of $\operatorname{nad}(\mathrm{p}) \mathrm{h}$ oxidase: Implications for protection against endotoxic shock in rats. FASEB J 2005, 19:1890-1892.

9. Sano K, Nakamura H, Matsuo T: Mode of inhibitory action of bilirubin on protein kinase c. Pediatr Res 1985, 19:587-590.

10. Fukui M, Tanaka M, Shiraishi E, Harusato I, Hosoda H, Asano M, Hasegawa G, Nakamura N: Relationship between serum bilirubin and albuminuria in patients with type 2 diabetes. Kidney Int 2008, 74:1197-1201. 
11. Targher G, Zoppini G, Cesare Guidi G, Lippi G: Relationship between serum bilirubin and kidney function in non-diabetic and diabetic individuals. Kidney Int 2009, 75:863.

12. Report of the expert committee on the diagnosis and classification of diabetes mellitus. Diabetes Care 2003, 26:S5-20,

13. Stevens LA, Coresh J, Greene T, Levey AS: Assessing kidney functionmeasured and estimated glomerular filtration rate. N Engl J Med 2006 , 354:2473-2483.

14. Kumar A, Pant P, Basu S, Rao GR, Khanna HD: Oxidative stress in neonatal hyperbilirubinemia. J Trop Pediatr 2007, 53:69-71.

15. Schwertner HA, Jackson WG, Tolan G: Association of low serum concentration of bilirubin with increased risk of coronary artery disease. Clin Chem 1994, 40:18-23.

16. Breimer LH, Wannamethee G, Ebrahim S, Shaper AG: Serum bilirubin and risk of ischemic heart disease in middle-aged british men. Clin Chem 1995, 41:1504-1508.

17. Djousse L, Levy D, Cupples LA, Evans JC, D'Agostino RB, Ellison RC: Total serum bilirubin and risk of cardiovascular disease in the framingham offspring study. Am J Cardiol 2001, 87:1196-1200.

18. Nakagami T, Toyomura K, Kinoshita T, Morisawa S: A beneficial role of bile pigments as an endogenous tissue protector: Anti-complement effects of biliverdin and conjugated bilirubin. Biochim Biophys Acta 1993, 1158:189-193.

19. Mietus-Snyder M, Friera A, Glass CK, Pitas RE: Regulation of scavenger receptor expression in smooth muscle cells by protein kinase c: A role for oxidative stress. Arterioscler Thromb Vasc Biol 1997, 17:969-978.

20. Koya D, King GL: Protein kinase c activation and the development of diabetic complications. Diabetes 1998, 47:859-866.

21. Roh DD, Kamanna VS, Kirschenbaum MA: Oxidative modification of lowdensity lipoprotein enhances mesangial cell protein synthesis and gene expression of extracellular matrix proteins. Am J Nephrol 1998, 18:344-350.

22. Suzuki D, Miyata T, Saotome N, Horie K, Inagi R, Yasuda Y, Uchida K, Izuhara Y, Yagame M, Sakai H, Kurokawa K: Immunohistochemical evidence for an increased oxidative stress and carbonyl modification of proteins in diabetic glomerular lesions. J Am Soc Nephrol 1999, 10:822-832.

23. Stehouwer CD, Gall MA, Twisk JW, Knudsen E, Emeis JJ, Parving HH: Increased urinary albumin excretion, endothelial dysfunction, and chronic low-grade inflammation in type 2 diabetes: Progressive, interrelated, and independently associated with risk of death. Diabetes 2002, 51:1157-1165.

24. de Alwis NM, Day CP: Non-alcoholic fatty liver disease: The mist gradually clears. J Hepatol 2008, 48:S104-112.

25. Chang Y, Ryu S, Sung E, Woo HY, Oh E, Cha K, Jung E, Kim WS: Nonalcoholic fatty liver disease predicts chronic kidney disease in nonhypertensive and nondiabetic Korean men. Metabolism 2008, 57:569-576.

26. Targher G, Chonchol M, Bertolini L, Rodella S, Zenari L, Lippi G, Franchini M, Zoppini G, Muggeo M: Increased risk of CKD among type 2 diabetics with nonalcoholic fatty liver disease. J Am Soc Nephrol 2008 , 19:1564-1570

\section{Pre-publication history}

The pre-publication history for this paper can be accessed here: http://www.biomedcentral.com/1471-2369/12/29/prepub

doi:10.1186/1471-2369-12-29

Cite this article as: Shin et al:: Relationship of serum bilirubin concentration to kidney function and 24-hour urine protein in Korean adults. BMC Nephrology 2011 12:29.

\section{Submit your next manuscript to BioMed Central and take full advantage of:}

- Convenient online submission

- Thorough peer review

- No space constraints or color figure charges

- Immediate publication on acceptance

- Inclusion in PubMed, CAS, Scopus and Google Scholar

- Research which is freely available for redistribution

Submit your manuscript at www.biomedcentral.com/submit
Ciomed Central 